\title{
Effect of Methamphetamine Exposure on Sexual Behavior and Locomotor Activity of Adult Male Rats
}

\author{
L. MIHALČÍKOVÁ ${ }^{1}$, A. OCHOZKOVÁ ${ }^{1}$, R. ŠLAMBEROVÁ ${ }^{1}$ \\ ${ }^{1}$ Department of Physiology, Third Faculty of Medicine, Charles University, Prague, Czech Republic
}

Received March 21, 2019

Accepted September 14, 2019

\section{Summary}

Drug addiction and its consequences on social life and behavior is currently a worldwide problem. Methamphetamine (MA) is one of the most abused psychostimulants in the Czech Republic. MA elevates mood, increases concentration, reduces appetite, and promotes weight loss. However, high doses and long-term abuse can induce psychosis, hallucinations, paranoia, violent behavior, and can lead to cardiovascular problems. Regarding its high prevalence and negative impact on health and social life, MA needs to be fully investigated. Previous studies have demonstrated the impairing effect of MA drug abuse on female behavior. However, MA's influence on male sexual behavior is not entirely clear. The aim of this study was to examine the effect of MA exposure on sexual behavior and spontaneous locomotor activity of adult male rats. MA was administrated subcutaneously at a dose of $5 \mathrm{mg} / \mathrm{kg}$ daily for a period of 30 days. The control group was exposed to saline (SA) at the same time and same volume. At the end of the application period, exposed male rats were paired with non-treated female rats, and their behavior was recorded for $2 \mathrm{~h}$. Sexual mating behavior was described in terms of mounting frequency, intromission frequency, ejaculation frequency, sniffing time, intromission latency and the postejaculatory interval. Spontaneous locomotor activity in postnatally exposed male rats was studied using the Laboras apparatus. Acute doses of MA (1 mg/kg) or SA were administrated to probe the sensitizing effect of previous chronic MA exposure. Afterward, the animal was placed in an unknown environment and monitored for $1 \mathrm{~h}$. Behavior was automatically evaluated using Laboras software by analyzing the following parameters: duration of locomotion (s), duration of immobility (s), rearing (vertical exploratory behavior), time spent grooming (s), average speed $(\mathrm{mm} / \mathrm{s})$, and distance traveled $(\mathrm{m})$. Our results indicate that MA administration has a negligible effect on the sexual behavior of adult male rats. However, more experiments have to be performed to examine the influence of MA exposure on spermatogenesis and the behavior of offspring. Data from the Laboras test showed that MA exposure has a significant effect on locomotor activity in both acute as well as subchronic MA application. In conclusion, our results show that administration of MA in adult male rats does not affect sexual performance and motivation but does increase locomotor and exploratory activity in an unknown environment.

\section{Key words}

Methamphetamine • Sexual behavior • Locomotor activity • Male rats $\bullet$ Drug abuse

\section{Corresponding author}

R. Šlamberová, Department of Physiology, Third Faculty of Medicine, Charles University, Ke Karlovu 458/4, 12000 Prague, Czech Republic. E-mail: romana.slamberova@lf3.cuni.cz

\section{Introduction}

Statistical surveys (European Drug ReportEmcdda 2010) have demonstrated that methamphetamine (MA) is one of the most abused "hard" drugs in the Czech Republic. Over the last decades, MA has also become more popular in other countries due to its low price and relatively simple production compared to other drugs such as cocaine or heroin (Marwick 2000). MA is a powerfully addictive psychostimulant that is metabolized slowly. Therefore, the effect of MA can last for a long time (up to $24 \mathrm{~h}$ ) and potentially evolve into drug abuse. Approximately $66 \%$ of registered drugabusing men and women in the Czech Republic use MA as a "first choice" drug (Vavřínková et al. 2001). Today, MA abuse represents a serious problem for human 
wellbeing. Recognizing patterns of abuse is key to minimizing the risk of its negative impact on health and social life (Chomchai et al. 2015).

Our previous studies demonstrated that administration of MA during pregnancy attenuates the maternal behavior of rat mothers (Šlamberová et al. 2005, Holubová et al. 2019). MA is highly lipid-soluble, it penetrates the brain-blood and placenta barriers, and it is secreted into maternal breast milk. Therefore, MA abuse among females can easily result in a negative impact on the development of offspring. Further, we found that prenatal MA exposure also affects the behavior of offspring in unknown environments (Schutová et al. 2013), involves anxiety-like behavior in the elevated plus-maze and open-field test (Schutová et al. 2009), affects learning when tested in the Morris water maze (Macúchová et al. 2013), and leads to greater susceptibility to drug sensitization in adulthood (Šlamberová et al. 2009). Alterations in behavioral patterns were manifested in aggressive and sexual behavior in adulthood, as well as an insignificant decrease in social interaction (Hol et al. 1999). The effect of MA exposure on social behavior was also seen in our studies of social interaction (Šlamberová et al. 2010). These studies mainly focused on maternal MA exposure and its impact on the development of offspring. The influence of paternal MA abuse on offspring development has not yet been thoroughly studied.

There are studies showing that cocaine (another psychostimulant drug) administration in adult male rats leads to hyperactivity and behavioral changes in rat pups (Abel et al. 1989). Studies by Bielawski et al. (1997, 2002) showed that paternal alcohol abuse resulted in offspring malformations, decreased mean fetal weight, and reduced the cytosine methyltransferase mRNA levels in paternal sperm cells. Many experiments have also found that cocaine abuse has an adverse effect on reproduction and spermatogenesis in males (George et al. 1996). Other studies have demonstrated the negative impact of cocaine and its metabolites on the function of Sertoli cells (Zhang et al. 1996) and that cocaine-induced apoptosis in sperm cells is significantly increased after only 15 days of drug exposure (Li et al. 1999). The effect of prenatal cocaine and morphine exposure also affects the development of spinal sexual reflexes in males (Vathy et al. 1998). Experiments performed using MA also showed differences in sexual behavior. A study by Kuiper et al. (2017) reports that MA administration leads to maladaptive sexual behavior, which was associated with alterations in neural activation of the brain. Studies by Frohmader et al. (2010) showed the effect of MA exposure on sexual motivation and performance. Despite the existing studies, it is important to further examine and clarify the effect of MA exposure, since drug abuse is still on the rise and represents a serious problem worldwide.

The above-mentioned studies suggest that subchronic drug exposure may induce decreased sperm cell production and result in changes in sexual behavior. Therefore, the first aim of the present study is to evaluate the impact of MA abuse on the sexual activity of adult male rats. Our previous studies showed that MA administration in adulthood increased overall activity, e.g. increased locomotor and exploratory behavior (Hrubá et al. 2012), while prenatal MA exposure mainly increased exploratory activity (Bubeníková-Valešová et al. 2009). We suggest that increased locomotion and exploration could also have an impact on sexual activity and behavior. Therefore, the second aim of our study was to determine the potential effect of MA abuse on nonsocial activities (locomotion and exploratory behavior) and its association with sexual behavior. To sum up, the aim of the present study is to examine the effect of MA on sexual behavior and general activity of adult male rats.

\section{Methods}

All experimental procedures performed in this study were reviewed and approved by the Institutional Animal Care and Use Committee in agreement with Czech Government Requirements under the Policy of Humans Care of Laboratory Animals (No. 246/1992) and subsequent regulations from the Ministry of Agriculture of the Czech Republic (No. 311/1997).

Adult, 90-day old male and female Albino Wistar rats were purchased from Velaz (Prague, Czech Republic) and raised by Charles River Laboratories International, Inc. Males (300-350 g) were housed 3 per cage, and females (250-300 g) were housed 4 per cage. All animals were left undisturbed for a week in a temperature-controlled $\left(22-24{ }^{\circ} \mathrm{C}\right)$ colony room with free access to food and water on a 12-hour light, 12-hour dark cycle with lights on at 6:00 a.m. After one week of acclimatization, males were randomly divided into MA-treated and saline-treated (control) groups. Males were exposed to MA (or saline) daily at 11 a.m., for a period of 30 days. 
This administration period was chosen in accordance to show the adverse impact of cocaine as also a psychostimulant on sexual behavior and spermatogenesis in male rats (Li et al. 1999). Study of Li et al. (1999) showed that after 15 days of cocaine exposure apoptosis of sperm cells significantly increased, peaked at 30 days and persisted up to 90 days. Therefore, 30 days of administration period was chosen as appropriate in our experiment. MA was administrated subcutaneously (SC) at a dose of $5 \mathrm{mg} / \mathrm{kg}$. This dose of MA induces similar behavioral changes as those seen in humans (Šlamberová et al. 2005), and therefore, this dose was used in our experiment. The control group was exposed to SC saline at the same time and in the same volume as the MA.

\section{Sexual behavior}

After 30 days of exposure, male rats were mated with non-treated females. As behavior in females can differ depending on the phase of the estrous cycle, the phase of the cycle was determined by vaginal lavage smears subsequently 2-3 days before mating. The smears were examined using light microscopy. At the onset of the estrous phase of the estrous cycle (Turner and Bagnara 1976), the males and receptive females were introduced into transparent plexiglass cages $(20 \times 20 \mathrm{x}$ $40 \mathrm{~cm}$ ), in a one male to one female ratio. The experiment was conducted after 5 p.m. in the laboratory under dim light. There were 2 groups of animals tested for sexual behavior (MA and SA, n=8, 16 animals tested in total). The occurrence and disappearance of phases of sexual mating were determined using the following parameters of mating behavior ( $\mathrm{Agmo}$ et al. 1995, Zanoli et al. 2005): number of mounts before ejaculation or mounting frequency (MF), number of intromissions before ejaculation or intromission frequency (IF), time from introduction of the female to the first intromission by the male or intromission latency (IL), ejaculatory frequency (EF), time between first and second ejaculation or postejaculatory interval and pre-coital sexual behaviors such as sniffing and nosing time (sec). The observed parameters were recorded for up to $2 \mathrm{~h}$ of pairing and used for further analysis (Kataria et al. 2013).

\section{Test of locomotor activity (the Laboras test)}

Different groups of adult male rats (MA and SA, $\mathrm{n}=8$ ) were used for testing exploratory and locomotor activity in the Laboras apparatus (Metris B.V., Netherlands). The Laboras is a fully automated system for continuous behavior recognition and tracking of small rodents (Schutová et al. 2013). It consists of a triangularshaped sensor platform connected to a computer. A Makrolon ${ }^{\circledR}$ type III cage $\left(840 \mathrm{~cm}^{2}\right)$, with a 3 -cm layer of bedding, is placed and held in a fixed position on the measurement platform. The platform transforms the mechanical vibrations evoked by the movements of the animal into electrical signals. Each movement pattern has its own unique frequency and amplitude, and thus separate behavioral categories can be easily distinguished and classified by the computer.

The Laboras test was conducted 7-10 days after last subchronic administration to examine the sensitizing effect of subchronic MA administration to a challenge dose. An acute dose of MA (1 mg/kg) or SA in a volume of $1 \mathrm{ml} / \mathrm{kg}$ was administered immediately prior to placing the animal in the Laboras cage to probe the sensitizing effect of the previous 30 days of MA treatment. Behavioral testing was performed from 12 p.m. to 6 p.m. in a darkened room. Before testing, each animal was weighed and moved to the testing room, where it remained in its home cage for a $30 \mathrm{~min}$ acclimation period. To sum up, the following experimental groups were tested: MA chronic/MA acute, MA chronic/SA acute, SA chronic/MA acute, and SA chronic/SA acute (4 groups in total, $n=8,32$ animals tested in total). Each animal was tested separately and recorded for $1 \mathrm{~h}$. As in our previous study (Šlamberová et al. 2018), the 1-hour period was divided into six consecutive 10-minute intervals used to follow changes in behavior during the habituation time in the Laboras apparatus. The following parameters were automatically evaluated by Laboras: time spent in locomotion (s), time spent immobile (s), time spent rearing (s), time spent grooming (s), distance traveled $(\mathrm{m})$, and average speed $(\mathrm{mm} / \mathrm{s})$.

\section{Statistical analysis}

Data from each test were analyzed as follows. Sexual behavior: Each parameter of sexual mating was analyzed separately using the $t$-test. Differences were considered significant if $\mathrm{p}<0.05$. Locomotor activity (Laboras): Experiment was analyzed by STATISTICA software. Each measured parameter was evaluated separately by using a two-way ANOVA (subchronic drug treatment $\mathrm{x}$ acute drug administration) with repeated measure (Intervals). The Bonferroni test was used for post hoc comparisons. Differences were considered significant if $\mathrm{p}<0.05$. 


\section{Results}

\section{Experiment Sexual behavior}

As shown in Figure 1, subchronic MA application (30 days) did not induced any statistically significant differences between MA males relative to mounting frequency $(p=0.17)$, intromission frequency $(p=0.59)$, and number of ejaculations $(p=0.73)$ compared to saline controls. There were also no significant differences in time spent sniffing $(\mathrm{p}=0.66)$. Moreover, our data showed that MA exposure does not affect the length of post-ejaculatory interval $(\mathrm{p}=0.83)$ and intromission latency $(\mathrm{p}=0.22)$.
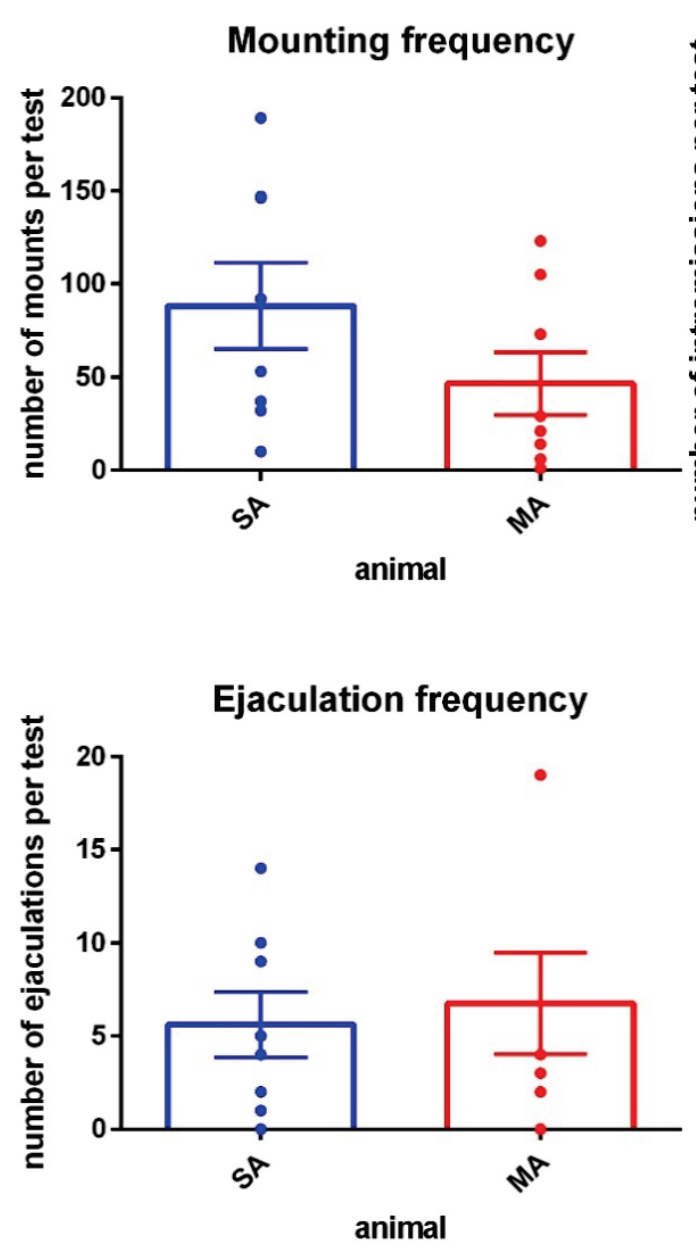

Intromission latency

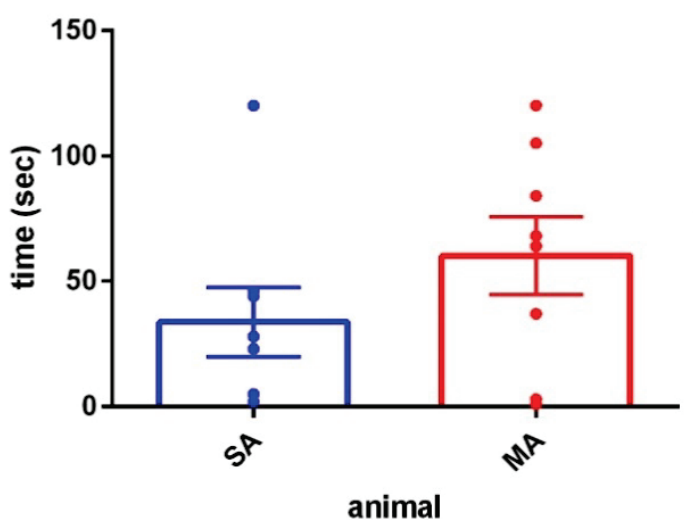

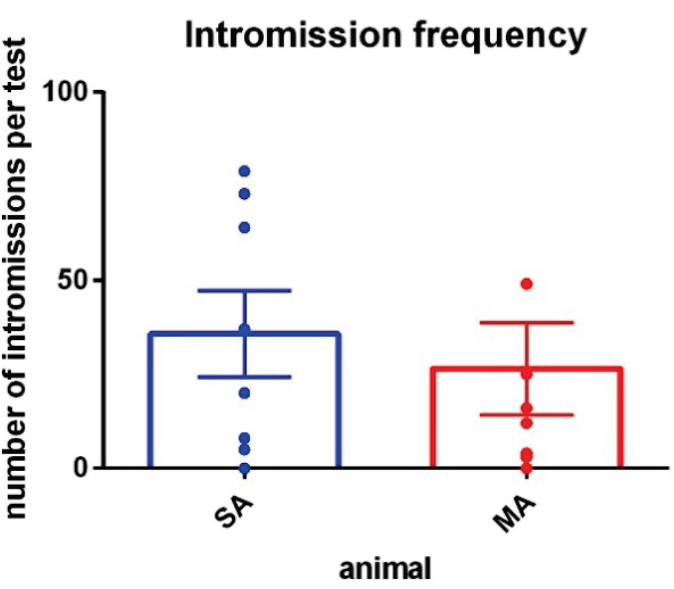

Sniffing time

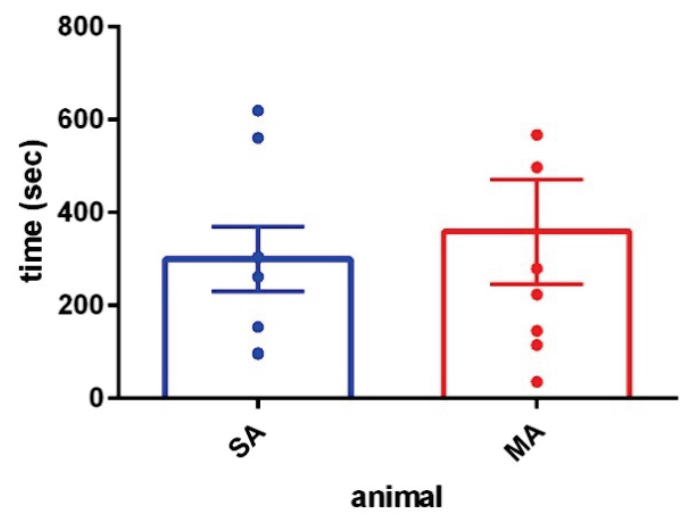

Post ejaculatory interval

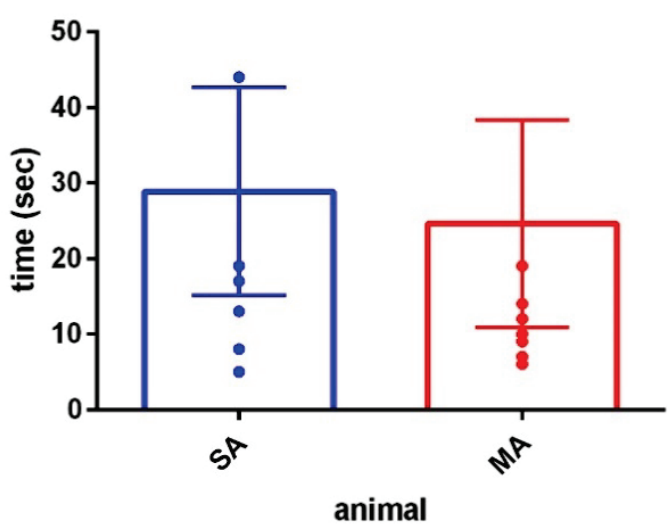

Fig. 1. The effect of subchronic MA exposure on sexual behavior. There were no significant differences between MA and SA exposed groups. $M A=$ methamphetamine, $S A=$ saline. Values are mean $\pm S E M(n=8)$. 


\section{Experiment of locomotor activity}

As shown in Figure 2, there was a main effect of acute application in all measures: locomotion $\left[\mathrm{F}_{(1,31)}=30.63 ; \mathrm{p}<0.05\right]$, average speed $\left[\mathrm{F}_{(1,31)}=27.57\right.$; $\mathrm{p}<0.05]$, distance traveled $\left[\mathrm{F}_{(1,31)}=27.57 ; \mathrm{p}<0.05\right]$, rearing $\left[\mathrm{F}_{(1,31)}=38.93 ; \mathrm{p}<0.05\right]$, grooming $\left[\mathrm{F}_{(1,31)}=23.03 ; \mathrm{p}<0.05\right]$ and immobility $\left[\mathrm{F}_{(1,31)}=36.52 ; \mathrm{p}<0.05\right]$. Moreover, there was an interaction between subchronic treatment, acute application and time the way that acute MA application increased locomotion $\left[\mathrm{F}_{(5,155)}=3.77 ; \mathrm{p}<0.05\right]$, average speed $\left[\mathrm{F}_{(5,155)}=2.92 ; \mathrm{p}<0.05\right]$, and distance traveled $\left[\mathrm{F}_{(5,155)}=2.92 ; \mathrm{p}<0.05\right]$ more in animals treated subchronically with saline than in animals with MA subchronic treatment within the $20^{\text {th }}$ and $50^{\text {th }}$ min of measure.
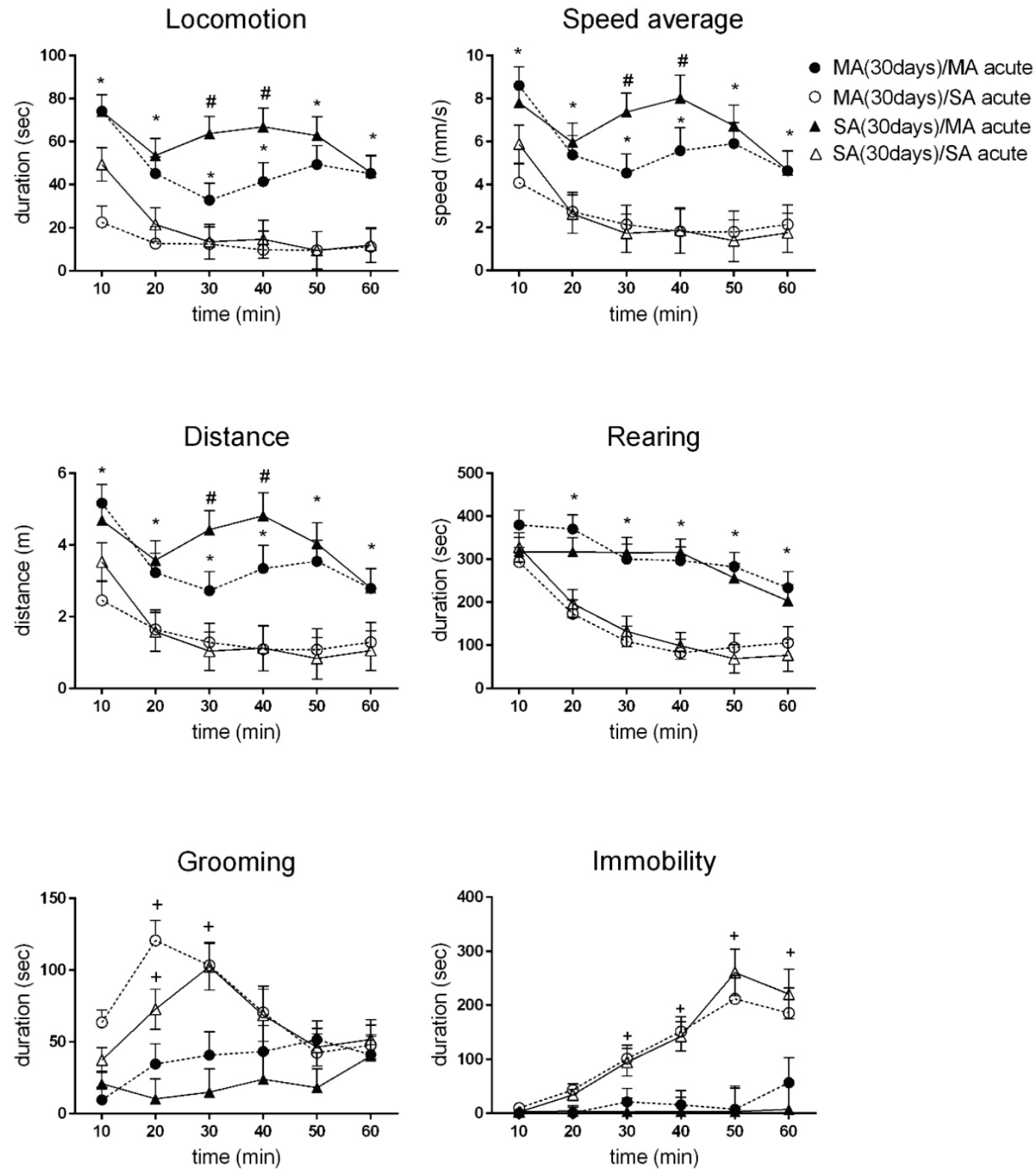

Fig. 2. The effect of acute and subchronic $M A$ exposure on locomotor and exploratory behavior in the Laboras test. $M A=$ methamphetamine, $S A=$ saline. Values are mean \pm SEM $(n=8) .{ }^{*} p<0.05$ acute MA $>$ acute $S A ;{ }^{*} p<0.05$ sub-chronic SA $>$ subchronic MA; ${ }^{+} \mathrm{p}<0.05$ acute $\mathrm{SA}>$ acute MA.

\section{Discussion}

The mechanism of action for MA is based on the release of dopamine, serotonin, and noradrenaline by the central nervous system and by blockade of their reuptake from synapses and into synaptic vessels (Rothman et al. 2001, Kish et al. 2007). A study by Kesby et al. (2018) showed that MA abuse increases brain glutamine levels as well as striatal dopamine and cortical serotonin levels in mice. Dopamine in the nigrostriatal tract influences 
motor activity, in the mesolimbic tract it activates numerous behaviors including copulation, and in the medial preoptic area it controls genital reflexes, copulatory patterns, and sexual motivation. Thus, dopamine mainly facilitates sexual activities. In addition, serotonin positively or negatively affects copulatory patterns such as erection and ejaculation by targeting a specific subtype of the 5-HT receptors (Hull et al. 2004). Previous studies showed that repeated d-amphetamine exposure facilitated sexual behavior in naïve male rats independently of the environment in which the drug was administered (Florino and Phillips 1999). However, studies by Frohmader et al. (2010) found that MA administration in male rats impairs sexual motivation and performance in a dose-dependent matter. In addition, low doses of MA did not disrupt sexual functions, and acute MA administration did not impair sexual interest and activity. Moreover, they found that MA pretreatment did not affect the expression of sexual behavior; however, they discovered that the association between MA and mating was essential for the development of compulsive sexual behavior and changes in the sex and drug reward systems (Frohmader et al. 2011). Our study performed after 30 days of MA exposure, is most similar to the pretreatment period. Therefore, our results, which found no effect of MA on sexual activity, correlate with previous findings that MA exposure does not affect sexual motivation and performance in pre-treated male rats.

Regarding the effect of MA on behavior in an unknown environment, our present data demonstrated an increase in locomotion, average speed, and distance traveled after a 30-day (subchronic) treatment and increased overall activity (increased locomotion, rearing, grooming, speed average and distance traveled) and decreased immobility after acute MA (1 mg/kg) administration in adulthood (Laboras test). Our findings of increased locomotion and exploration, agree with other studies that found that psychostimulants, such as MA, increase locomotor activity (Glatt et al. 2000, Hall et al. 2008, Schutová et al. 2013).

The increased locomotor activity seen in MA-exposed male rats is mainly associated with increased levels of dopamine, especially in the nucleus accumbens (Bubeníková-Valešová et al. 2009).

Our data also showed that the effect of MA administration on locomotor activity does not influence sexual behavior. Thus, increased locomotor activity does not lead to increased sexual activity. An explanation for this finding could be that an acute dose of MA $(1 \mathrm{mg} / \mathrm{kg})$ mainly leads to increased locomotor activity, while sexual activity in MA exposed rats is dose-dependent and acute doses of MA are too low to initiate increased sexual activity.

In conclusion, our results show that administration of MA in adult male rats does not affect sexual performance and motivation but does increase locomotor and exploratory activity in an unknown environment. Future studies are planned to examine the effect of subchronic MA administration on spermatogenesis and testosterone levels in MA-exposed male rats.

\section{Conflict of Interest}

There is no conflict of interest.

\section{Acknowledgements}

This work was supported by research program Progres Q35, GAUK 560317, GACR 18-03806S and 260388/SVV/2019. This work was further supported by ERDF/ESF project "PharmaBrain" CZ.02.1.01/0.0/0.0/ 16_0250007444 funded from OP VVV. The authors express their appreciation to Thomas Secrest, for editing of the manuscript.

\section{References}

ABEL EL: Paternal behavioral mutagenesis. Neurotoxicology 10: 335-345, 1989.

ÅGMO A, VILLALPANDO A, PICKER Z, FERNÁNDEZ H: Lesions of the medial prefrontal cortex and sexual behavior in the male rat. Brain Res 696: 177-186, 1995.

BIELAWSKI DM, ABEL EL: Acute treatment of paternal alcohol exposure produces malformations in offspring. Alcohol 14: 397-401, 1997.

BIELAWSKI DM, ZAHER FM, SVINARICH DM, ABEL EL: Paternal alcohol exposure affects sperm cytosine methyltransferase messenger RNA levels. Alcohol Clin Exp Res 26: 347-351, 2002.

BUBENÍKOVÁ-VALEŠOVÁ V, KAČER P, SYSLOVÁ K, RAMBOUSEK L, JANOVSKÝ M, SCHUTOVÁ B, ŠLAMBEROVÁ R: Prenatal methamphetamine exposure affects the mesolimbic dopaminergic system and behavior in adult offspring. Int J Dev Neurosci 27: 525-530, 2009. 
CHOMCHAI C, CHOMCHAI S: Global patterns of methamphetamine use. Curr Opin Psychiatry 28: 269-274, 2015.

DAVIES C, ENGLISH L, LODWICK A, MCVEIGH J, BELLIS MA: United Kingdom drug situation: annual report to the European Monitoring Centre for Drugs and Drug Addiction (EMCDDA) 2010.

FIORINO DF, PHILLIPS AG: Facilitation of sexual behavior and enhanced dopamine efflux in the nucleus accumbens of male rats after D-amphetamine-induced behavioral sensitization. $J$ Neurosci 19: 456-463, 1999.

FROHMADER KS, BATEMAN KL, LEHMAN MN, COOLEN LM: Effects of methamphetamine on sexual performance and compulsive sex behavior in male rats. Psychopharmacology 212: 93-104, 2010.

FROHMADER KS, LEHMAN MN, LAVIOLETTE SR, COOLEN LM: Concurrent exposure to methamphetamine and sexual behavior enhances subsequent drug reward and causes compulsive sexual behavior in male rats. J Neurosci 31: 16473-16482, 2011.

GEORGE VK, LI H, TELOKEN C, GRIGNON DJ, LAWRENCE WD, DHABUWALA CB: Effects of long-term cocaine exposure on spermatogenesis and fertility in peripubertal male rats. J Urol 155: 327-331, 1996.

GLATT SJ, BOLAÑOS CA, TRKSAK GH, CROWDER-DUPONT C, JACKSON D: Prenatal cocaine exposure alters behavioral and neurochemical sensitization to amphetamine in adult rats. Neuropharmacology 39: 599-610, 2000.

HALL DA, STANIS JJ, AVILA HM, GULLEY JM: A comparison of amphetamine-and methamphetamine-induced locomotor activity in rats: evidence for qualitative differences in behavior. Psychopharmacology 195: 469-478, 2008.

HOL T, VAN DEN BERG CL, VAN REE JM, SPRUIJT BM: Isolation during the play period in infancy decreases adult social interactions in rats. Behav Brain Res 100: 91-97, 1999.

HOLUBOVÁ A, PONIŠT S, JURČOVIČOVÁ J, ŠLAMBEROVÁ R: Different oxytocin responses to acute methamphetamine treatment in juvenile female rats perinatally exposed to stress and/or methamphetamine administration. Front Physiol 10, 2019.

HRUBÁ L, SCHUTOVÁ B, ŠLAMBEROVÁ R: Sex differences in anxiety-like behavior and locomotor activity following prenatal and postnatal methamphetamine exposure in adult rats. Physiol Behav 105: 364-370, 2012.

HULL EM, MUSCHAMP JW, SATO S: Dopamine and serotonin: influences on male sexual behavior. Physiol Behav 83: 291-307, 2004.

KATARIA S, KAUR D, RAO SK, KHAJURIA RK: In vitro and in vivo aphrodisiac properties of Corchorus depressus Linn. on rabbit corpus cavernosum smooth muscle relaxation and sexual behavior of normal male rats. J Ethnopharmacol 148: 210-217, 2013.

KESBY JP, CHANG A, MARKOU A, SEMENOVA S: Modeling human methamphetamine use patterns in mice: chronic and binge methamphetamine exposure, reward function and neurochemistry. Addict Biol 23: 206-218, 2018.

KISH SJ, TONG J, HORNYKIEWICZ O, RAJPUT A, CHANG LJ, GUTTMAN M, FURUKAWA Y: Preferential loss of serotonin markers in caudate versus putamen in Parkinson's disease. Brain 131: 120-131, 2007.

KUIPER LB, FROHMADER KS, COOLEN LM: Maladaptive sexual behavior following concurrent methamphetamine and sexual experience in male rats is associated with altered neural activity in frontal cortex. Neuropsychopharmacology 42: 2011-2020, 2017.

LI H, JIANG Y, RAJPURKAR A, DUNBAR JC, DHABUWALA CB: Cocaine induced apoptosis in rat testes. $J$ Urol 162: 213-216, 1999.

MACÚCHOVÁ E, NOHEJLOVÁ-DEYKUN K, ŠLAMBEROVÁ R: Effect of methamphetamine on cognitive functions of adult female rats prenatally exposed to the same drug. Physiol Res 62 (Suppl 1): S89-S98, 2013.

MARWICK CH: NIDA seeking data on effect of fetal exposure to methamphetamine. JAMA 283: 2225-2226, 2000.

ROTHMAN RB, BAUMANN MH, DERSCH CM, ROMERO DV, RICE KC, CARROLL FI, PARTILLA JS: Amphetamine-type central nervous system stimulants release norepinephrine more potently than they release dopamine and serotonin. Synapse 39: 32-41, 2001.

SCHUTOVÁ B, HRUBÁ L, POMETLOVÁ M, DEYKUN K, ŠLAMBEROVÁ R: Cognitive functions and drug sensitivity in adult male rats prenatally exposed to methamphetamine. Physiol Res 58: 741-750, 2009. 
SCHUTOVÁ B, HRUBÁ L, ROKYTA R, ŠLAMBEROVÁ R: Gender differences in behavioral changes elicited by prenatal methamphetamine exposure and application of the same drug in adulthood. Dev Psychobiol 55: 232-242, 2013.

S̆LAMBEROVÁ R, CHAROUSOVÁ P, POMETLOVÁ M: Methamphetamine administration during gestation impairs maternal behavior. Dev Psychobiol 46: 57-65, 2005.

ŠLAMBEROVÁ R, MIKULECKÁ A, POMETLOVÁ M, SCHUTOVÁ B, HRUBÁ L, DEYKUN K: The effect of methamphetamine on social interaction of adult male rats. Behav Brain Res 214: 423-427, 2010.

ŠLAMBEROVÁ R, NOHEJLOVÁ K, OCHOZKOVÁ A, MIHALČÍKOVÁ L: What is the role of subcutaneous single injections on the behavior of adult male rats exposed to drugs? Physiol Res 67 (Suppl 4): S665-S672, 2018.

ŠLAMBEROVÁ R, SCHUTOVÁ B, MATĚJOVSKÁ I, BERNÁŠKOVÁ K, ROKYTA R: Effects of a single postnatal methamphetamine administration on NMDA-induced seizures are sex-and prenatal exposure-specific. Naunyn Schmiedebergs Arch Pharmacol 380: 109-114, 2009.

TURNER CD, BAGNARA JT: Biological effects of the ovarian hormones. Gen Endocrinol 6: 466-476, 1976.

VATHY I, VELÍŠKOVÁ J, MOSHÉ SL: Prenatal morphine exposure induces age-related changes in seizure susceptibility in male rats. Pharmacol Biochem Behav 60: 635-638, 1998.

VAVŘINKOVÁ B, BINDER T, ŽIVNÝ J: Characteristics of a population of drug dependent pregnant women in the Czech Republic. (Article in Czech) Ceska Gynekol 66: 285-291, 2001.

ZANOLI P, ZAVATTI M, RIVASI M, BARALDI M: Ferula hermonis impairs sexual behavior in hormone-primed female rats. Physiol Behav 86: 69-74, 2005.

ZHANG H, LOUGHLIN KR: The effect of cocaine and its metabolites on Sertoli cell function. $J$ Urol 155: 163-166, 1996. 